\title{
Earthworm Depuration: Analysis of Coprophagy and Light Impacts
}

\author{
Katherine E. Messer and Ann C. Wilkie \\ Institute of Food and Agricultural Sciences, University of Florida
}

Faculty Mentor: Ann C. Wilkie, Soil and Water Sciences Department

\begin{abstract}
Earthworms are used as biomarkers to determine the bioavailability of contaminants. As such, their uptake of contaminants has been studied extensively. Protocols have been established to ensure that laboratory-obtained data are valid and comparable. However, the method of removing the organism's gut content (depuration) before assessing the contaminant in the tissue is not standardized. The aim of this research project was to investigate some parameters for earthworm depuration: light conditions and coprophagy prevention. Eisenia fetida were depurated for 48 hours in two separate studies according to existing guidelines. In one study, under continuous light conditions, two frequencies of egesta removal were employed during depuration to prevent coprophagy and compared to the control (egesta and worms removed after 48 hours). In another study, the subjects and material egested were assessed under conditions of continuous darkness and compared to the control (continuous light). The depuration methods that included egesta removal every 12 and 24 hours resulted in $62 \%$ and $9 \%$ more egested material per mg of earthworm than the control (egesta removal after 48 hours), respectively. The earthworms depurated in continuous darkness egested $98 \%$ more material per mg of earthworm than the control. The results indicate that there was more complete depuration under continuous darkness or when employing a coprophagy prevention method under continuous light. These findings could lead to more efficient depuration methods.

Keywords: Eisenia fetida, depuration, bioaccumulation, gut voidance, gut kinetics, coprophagy
\end{abstract}

\section{Introduction}

Earthworms make up $89-92 \%$ of the invertebrate biomass in temperate terrestrial ecosystems and are an important food source for predators (Diercxsens et al., 1985). The abundance of earthworms and their sensitivity to environmental contaminants make them a model organism for assessing the potential ecological risk of toxic materials and heavy metals (Shi et al., 2017). Earthworms are treated as indicators of the effects that a contaminant could have on other terrestrial organisms. To assess the ecological risk of a material, two parameters must be determined: the amount of material biologically available to produce systemic effects in the 
organism and what those systemic effects are. The bioavailability of a material excludes both the gut contents and materials that become inactive after absorption (Toutain \& Bousquet-Mélou, 2004). A bioaccumulation test is used to measure the bioavailability of a substance in terrestrial organisms. Several international standards organizations have developed bioaccumulation test protocols, but the protocols deviate and a review by Nahmani et al. (2007a) concluded that more efforts to standardize these tests are necessary. The tests referenced in this study include ASTME1676 (ASTM, 2021) and OECD Test No. 317 (OECD, 2010). Generally, the test is performed on Eisenia fetida or Eisenia andrei, due to their availability and high reproduction rates.

Depending on the test design, the earthworms are exposed to the contaminant in a controlled environment or harvested from an environment that is already contaminated. After this period of exposure or "uptake", the earthworms are required to purge their guts before the tissue is analyzed to assess the amount of contaminant that remains in the tissue. Dissection has been used to remove gut tissue, but this method is labor intensive and often results in loss of tissue (Morgan and Morgan, 1989). The most prominent method of depuration is gut voidance in a petri dish on moist filter paper for 24-48 hours. Standards ASTM-E1676 and OECD Test No. 317 provide justification for their respective depuration periods (Richards and Ireland, 1978; Vijver et al., 2005), but the two tests disagree on the light conditions during purging and neither address coprophagy (Table 1).

Coprophagy, the act of eating feces, is mentioned in the literature as a phenomenon that requires preventive measures (Table 2), yet it is not acknowledged in protocols. Coprophagy prevention usually occurs in the form of filter paper changes every 12-24 hours to remove egesta. The depuration conditions used in previous studies are listed in Table 2, with studies that used a coprophagy prevention method shown in the bottom half of the table.

Light conditions vary widely within the literature and across standards (Table 2). Worms live primarily below ground and are sensitive to light exposure. Light induced paralysis/death has been observed in the nematode worm Caenorhabditis elegans (Ward et al., 2008). This same type of death has not been documented in the earthworm (an annelid), but they are known to be more sensitive to light in the extended state and their photoreceptors become saturated in prolonged light exposure (Harper, 1905). This suggests that prolonged light exposure reduces earthworm locomotion and potentially reduces casting production. 
Table 1. Comparison of depuration protocols in bioaccumulation test standards.

\begin{tabular}{|c|c|c|}
\hline Parameter & ASTM-E1676 & OECD Test No. 317 \\
\hline Duration & $24-48$ hours & 24 hours \\
\hline Temperature & $10-26^{\circ} \mathrm{C}$ & $20 \pm 2^{\circ} \mathrm{C}$ \\
\hline Light Conditions & $\begin{array}{l}\text { Continuous lighting using a fluorescent or } \\
\text { an incandescent light source with a } \\
\text { minimum intensity of } 37 \mathrm{fc}(400 \mathrm{lux})\end{array}$ & $\begin{array}{l}16: 8 \text { hours light/dark cycle where } \\
\text { the light period is } 400-800 \text { lux }\end{array}$ \\
\hline Environment & Petri dishes with wet filter paper & $\begin{array}{l}\text { A covered petri dish with moist } \\
\text { filter paper }\end{array}$ \\
\hline Coprophagy Prevention & None & None \\
\hline
\end{tabular}

Table 2. Comparison of depuration conditions used in previous studies.

\begin{tabular}{|c|c|c|c|c|}
\hline Study & Worm Species & $\begin{array}{l}\text { Depuration } \\
\text { Length (hr) }\end{array}$ & $\begin{array}{l}\text { Coprophagy Avoidance } \\
\text { Measure (Filter Paper } \\
\text { Change Frequency) }\end{array}$ & $\begin{array}{l}\text { Light Regimen } \\
\text { During Depuration }\end{array}$ \\
\hline Crossley et al. (1995) & Eisenia fetida & 100 & $\begin{array}{l}\text { Every } 2 \mathrm{hr} \text { for the first } 24 \\
\text { hr; then every } 20 \mathrm{hr} \text { until } \\
100 \mathrm{hr}\end{array}$ & Not given \\
\hline Sheppard et al. (1997) & Lumbricus terrestris & 120 & None & $12 \mathrm{hr}$ of light/day \\
\hline Callaham and Hendrix (1998) & Diplocardia sp. & 36 & None & Not given \\
\hline González and Zou (1999) & Pontoscolex corethrurus & 48 & None & Not given \\
\hline Lachnicht et al. (2002) & $\begin{array}{l}\text { Estherella sp. } \\
\text { Pontoscolex corethrurus }\end{array}$ & 24 & None & Not given \\
\hline Nahmani et al. (2007b) & Eisenia fetida & 48 & Every $12 \mathrm{hr}$ & Constant Darkness \\
\hline Carter et al. (2016) & Eisenia fetida & 24 & None & Not given \\
\hline Hu et al. (2016) & Eisenia andrei & 24 & None & $12 \mathrm{hr}$ of light/day \\
\hline Panzarino et al. (2016) & Eisenia andrei & 24 & None & Constant Darkness \\
\hline Xiao et al. (2021) & Eisenia fetida & 24 & None & Constant Darkness \\
\hline \multicolumn{5}{|c|}{ The following studies were searched with "coprophagy" in the keywords field. } \\
\hline Doube et al. (1997) & $\begin{array}{l}\text { Lumbricus terrestris } \\
\text { Lumbricus rubellus } \\
\text { Aporrectodea caliginosa } \\
\text { Aporrectodea longa }\end{array}$ & 96 & Every $48 \mathrm{hr}$ & Not given \\
\hline Lemtiri et al. (2016) & Eisenia fetida & 48 & Every $8 \mathrm{hr}$ & $16 \mathrm{hr}$ of light/day \\
\hline Richardson et al. (2016) & $\begin{array}{l}\text { Amynthas agrestis } \\
\text { Lumbricus rubellus }\end{array}$ & 72 & Every $12 \mathrm{hr}$ & Darkness \\
\hline Tatsi (2017) & Eisenia fetida & 24 & Every 12 hr & Constant Darkness \\
\hline Wijayawardena et al. (2017) & Eisenia fetida & 24 & Every $12 \mathrm{hr}$ & $8 \mathrm{hr}$ of light/day \\
\hline Tang et al. (2018) & Eisenia fetida & 96 & Changed periodically & Constant Light \\
\hline Tatsi et al. (2018) & Eisenia fetida & 48 & Every $12 \mathrm{hr}$ & $12 \mathrm{hr}$ of light/day \\
\hline Wijayawardena et al. (2018) & Eisenia fetida & 24 & Every $12 \mathrm{hr}$ & $8 \mathrm{hr}$ of light/day \\
\hline Abd Aziz et al. (2019) & Eisenia fetida & 48 & Every $24 \mathrm{hr}$ & $16 \mathrm{hr}$ of light/day \\
\hline
\end{tabular}


Incomplete gut voidance impacts the totality of the depuration and leads to overestimation of the end metric of many bioaccumulation tests (Nahmani et al., 2007a). Most bioaccumulation tests use the steady-state bioaccumulation factor (BAF) as the test endpoint according to ASTME1676. The BAF is calculated both as a steady-state term and as a kinetic term. The steady-state term (Eqn. 1) is a ratio of contaminant concentration in the tissue of the model organism over the concentration of contaminant in the medium the model was exposed to. The kinetic term (Eqn. 2) is a ratio of the uptake rate constant and the elimination rate constant (assuming first order kinetics) (USEPA, 2000).

$$
\begin{gathered}
B A F=\frac{C_{t}}{C_{s}} \\
B A F_{k}=\frac{k_{s}}{k_{c}}
\end{gathered}
$$

where

$$
\begin{gathered}
\qquad C_{t}=\text { the concentration in the tissue } \\
C_{s}=\text { the concentration in the soil } \\
k_{s}=\text { the rate constant of uptake from soil } \\
k_{c}=\text { the rate constant of elimination from the test organism }
\end{gathered}
$$

Both terms assess the accumulation of the contaminant in the tissue of the model. The gut content needs to be excluded from the BAF since the concentration of contaminant in the gut contents would be higher than the concentration absorbed by the test organism (Mount et al., 1999). BAF models have been shown to be more accurate for terrestrial test organisms and result in less false negatives than their counterpart, bioconcentration factors (BCFs), which only considers the contaminant accumulated at the respiratory surface and excludes the dietary exposure. Standardizing the methods to assess BAFs could increase their prevalence in the field and benefit environmental regulation policy formation (Costanza et al., 2012; Oorts et al., 2021).

Based on coprophagy prevention methods reported in the literature and the metabolic activity of earthworms in darkness conditions, this study investigated egesta production of E. fetida during depuration with coprophagy prevention methods and different light conditions. The hypothesis was made that (1) coprophagy prevention methods and (2) continuous darkness during depuration would result in more complete gut voidance. Two separate studies were conducted using E. fetida over the course of 48 hours. The study using coprophagy prevention 
methods, abbreviated Study CP, consisted of 3 triplicates of petri dishes maintained under continuous light conditions with 3 different filter paper change frequencies: every 12 hours, every 24 hours, and after 48 hours. The light conditions study, abbreviated Study LC, involved triplicates of petri dishes maintained in complete darkness and under light conditions of 13.67 $\mu \mathrm{mol} / \mathrm{m}^{2} / \mathrm{s}$ ( 700 lux). Gut voidance totality was assessed by examining the gastrointestinal tract for visible ingested matter and measuring the egested material, or egesta, as a percentage of the initial fresh weight per earthworm.

\section{Materials and Methods}

\section{Earthworm Cultivation and Characterization}

The earthworms used in both studies were collected from a vermiculture unit at the BioEnergy and Sustainable Technology Laboratory, Soil and Water Sciences Department, University of Florida-IFAS in Gainesville, Florida. A dichotomous key was used to confirm their genus and species based on external physical features (Dindal, 1990). The worms were harvested in spring 2021, and the species was determined to be E. fetida, an epigeic (surface dwelling) earthworm (Fig. 1). They were cultured on a fruit and vegetable waste (FVW) diet in a $16.6 \mathrm{~L}$ vermiculture unit at ambient room temperature $\left(22 \pm 2^{\circ} \mathrm{C}\right)$. FVW and shredded paper were added to the culture every 3 days in a 1:1 carbon to nitrogen ratio.

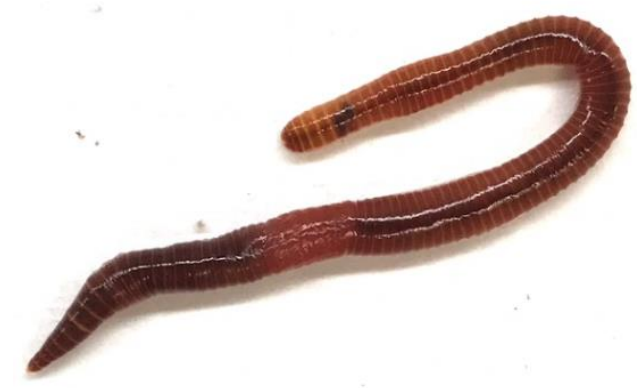

Figure 1. Fully mature Eisenia fetida cultured at the Bioenergy and Sustainable Technology Laboratory. 


\section{Earthworm Preparation}

Clitellated worms (fully mature) were harvested from the vermicomposter via hand sorting and rinsed with deionized water (DI). After being patted dry to remove excess moisture, they were placed on a petri dish and weighed on a scale (Mettler AE-163, Toledo, OH) in groups of three per variable group. The earthworm weight for each petri dish was documented at the beginning and end of each 48-hour study. After weighing, the groups of worms were placed on P8 Grade Fisherbrand ${ }^{\mathrm{TM}}$ filter paper discs moistened with $1 \mathrm{~mL}$ of DI water per petri dish. The petri dishes were maintained at ambient room temperature $\left(22 \pm 2^{\circ} \mathrm{C}\right)$. Petri dishes were sealed with scotch tape on two sides to prevent escape and still allow air permeation. In both studies, the filter paper discs were remoistened after 24 hours with $1 \mathrm{~mL}$ of DI water to prevent excessive dryness and stress related to water loss. Previously, when the paper discs were allowed to dry out, the earthworms were observed to produce coelomic fluid (Messer and Wilkie, unpublished), a yellow fluid containing metabolites that earthworms secrete when stressed (Dindal, 1990), as shown in Figure 2. The secretion of coelomic fluid leads to a loss of contaminant in the tissue and an underestimation of the BAF (Porfido et al., 2019).

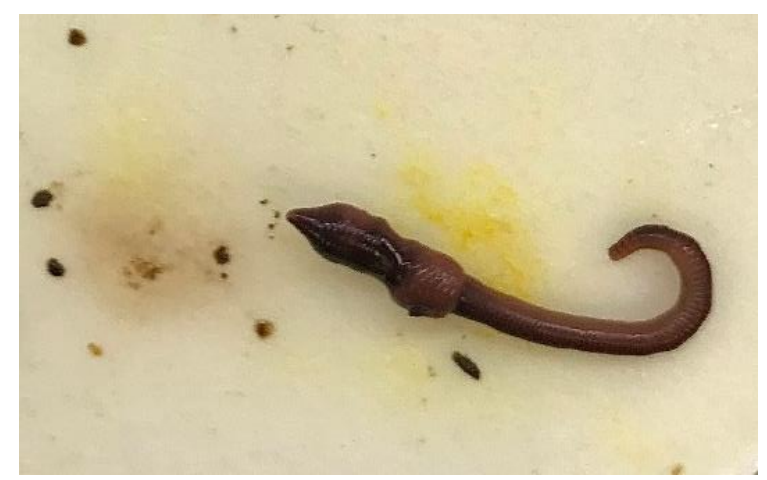

Figure 2. Eisenia fetida producing coelomic fluid after 72 hours with an initial $1 \mathrm{~mL}$ of DI water.

\section{Depuration Conditions and Data Collection}

\section{Study CP: Coprophagy Prevention Methods}

Three triplicate petri dishes with 3 earthworms each were maintained under light conditions of $13.67 \mu \mathrm{mol} / \mathrm{m}^{2} / \mathrm{s}$ for 48 hours in their respective conditions. Petri dish setup and numbering is shown in Figure 3. Filter paper discs and egesta were removed every 12 hours for petri dishes 
1-3, every 24 hours for petri dishes 4-6, and after 48 hours for petri dishes 7-9 (Fig. 3). Each time the filter paper discs and egesta were removed, they were dried at $40^{\circ} \mathrm{C}$ for 24 hours according to the egesta quantification methods of Arnold \& Hodson (2007). After drying, the paper discs were weighed with and without egesta to establish the dry weight of egesta. For petri dishes 7-9, the filter paper discs were also remoistened after 24 hours to prevent stress related to moisture loss.

After 48 hours, the earthworms were weighed again in their original groups of 3 to establish the final earthworm weight per petri dish. This measurement was used to calculate the average weight loss for the individual earthworms in each variable group (Table 3).

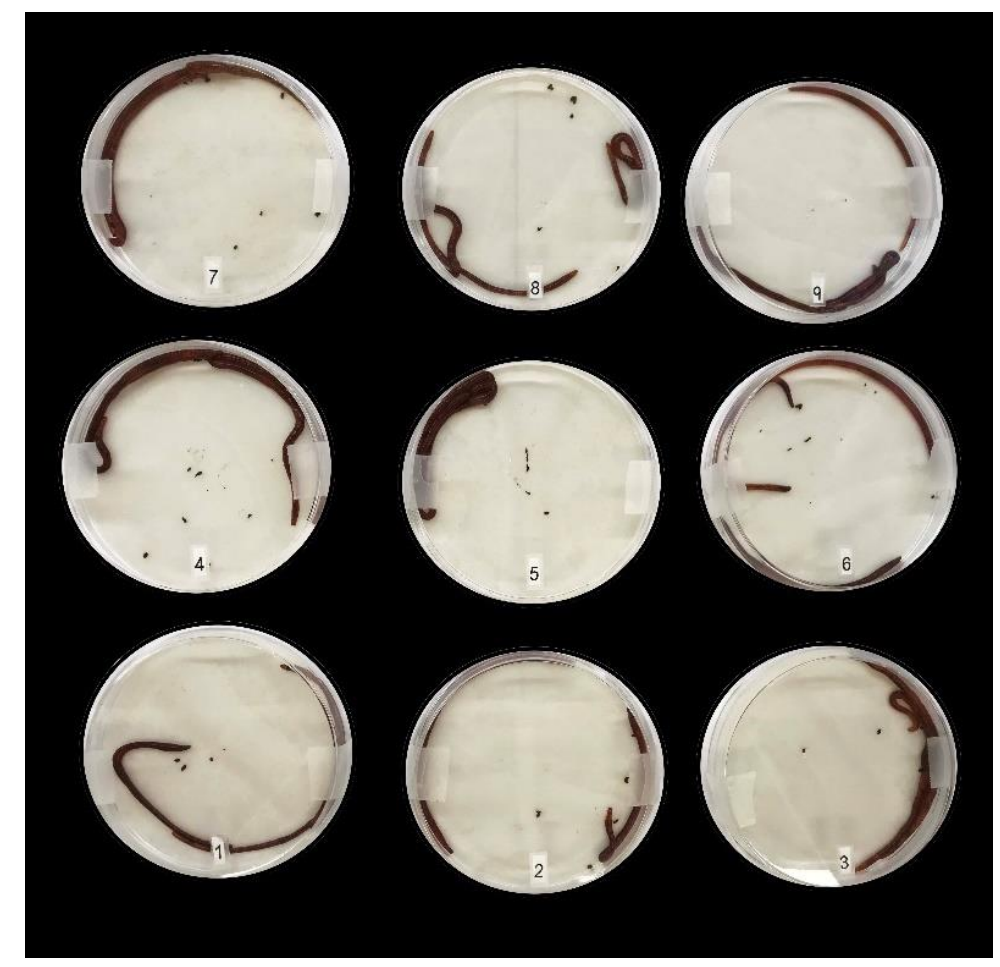

Figure 3. Worms depurated with coprophagy prevention: Filter paper discs changed every 12 hours (bottom row), every 24 hours (middle row), after 48 hours (top row).

\section{Study LC: Light Conditions}

Two triplicate petri dishes with 3 worms each were maintained for 48 hours in their respective conditions. Petri dishes 1-3 in Figure 4 were set up under continuous darkness. Petri dishes 4-6 in Figure 4 were set up under light conditions of $13.67 \mu \mathrm{mol} / \mathrm{m}^{2} / \mathrm{s}$. At 24 hours, all filter paper discs were remoistened with $1 \mathrm{~mL}$ of DI water. After 48 hours, filter papers were collected and dried at $40^{\circ} \mathrm{C}$ for 24 hours according to the egesta quantification methods 
performed by Arnold \& Hodson (2007). After drying, the paper discs were weighed with and without egesta to establish the dry weight of egesta.

After 48 hours, the earthworms were weighed again in their original groups of 3 to establish the final earthworm weight per petri dish. This measurement was used to calculate the average weight loss for the individual earthworms in each variable group (Table 3).

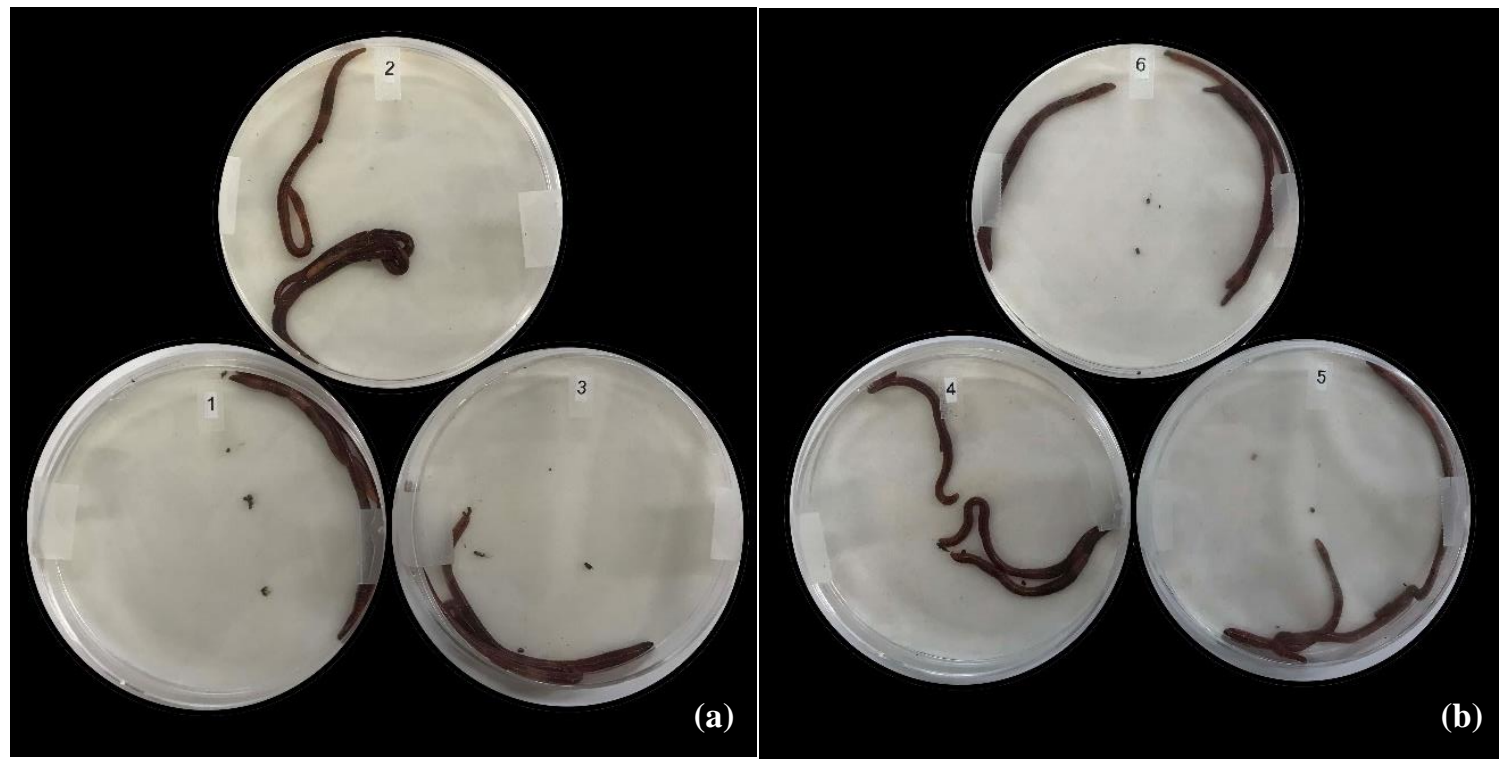

Figure 4. Worms depurated in light conditions (a) and worms depurated in dark conditions (b).

\section{Data Processing}

The weight of egesta was found after drying by subtracting the weight of each individual dried paper disc from the weight of the dried paper disc with egesta. The weight of egesta was then normalized by the fresh weight of the 3 responsible earthworms, resulting in the unit below:

$$
W_{e / f}=\frac{\text { dry weight of egesta } \times 100}{\text { total initial fresh weight }}
$$

In Study LC, this metric was calculated at the endpoint for each petri dish. In Study CP, this metric was calculated at each filter paper disc removal and plotted over time in JMP Pro (SAS Institute, Cary, NC). A best fit model was produced for the triplicate that produced data every 12 hours (petri dishes 1-3), and that model was forced fit on the triplicates with less data points (petri dishes 4-9) to estimate the $W_{e / f}$ during specific time periods. 
Average loss of fresh weight per earthworm for each petri dish was established using the following formula:

Average Individual Weight Loss $=\frac{\text { total initial fresh weight }- \text { total final fresh weight }}{3}$

The results from each petri dish were then averaged to find the average individual weight loss for each variable group: Average Weight Loss. The percent of fresh weight loss for the average worm in each variable group (Table 3) was found using equation 5.

$$
\text { Average } \% \text { Weight Loss }=\frac{\text { Average Weight Loss } \times 100}{\text { Average Initial Weight }}
$$

\section{Results}

\section{Earthworm Mass}

The bioaccumulation test standards require that mortality not exceed $10 \%$ and that mean mass loss at the end of the uptake and elimination phase not exceed $20 \%$ of initial fresh weight at the start of each individual phase (ASTM, 2021; OECD, 2010). Mortality for both Study CP and Study LC was $0 \%$ and mean mass loss did not exceed 20\% (Table 3). Both studies used worms that fit the test organism profile established by the OECD and ASTM standards. These standards require that earthworms be approximately the same weight and that the average individual weight be upwards of $300 \mathrm{mg}$.

Table 3. Initial fresh weight (mg) and average weight loss of earthworms after 48 hours.

\begin{tabular}{|c|c|c|c|c|c|}
\hline \multirow{2}{*}{ Variable Group } & \multicolumn{3}{|c|}{ Initial Average Weight Per Worm } & \multirow{2}{*}{$\begin{array}{c}\text { Triplicate } \\
\text { Average } \pm \text { SD }\end{array}$} & \multirow{2}{*}{$\begin{array}{c}\text { Average \% } \\
\text { Weight Loss } \\
\text { Per Worm }\end{array}$} \\
\hline & Sample 1 & Sample 2 & Sample 3 & & \\
\hline \multicolumn{6}{|l|}{ Filter Change } \\
\hline Every 12 Hours & 350.967 & 423.800 & 397.833 & $390.867 \pm 36.913$ & $19.75 \%$ \\
\hline Every 24 Hours & 594.100 & 462.300 & 422.133 & $492.844 \pm 89.960$ & $15.60 \%$ \\
\hline $\begin{array}{l}\text { After } 48 \text { Hours } \\
\text { (Control) }\end{array}$ & 461.767 & 453.800 & 413.233 & $442.933 \pm 26.028$ & $12.81 \%$ \\
\hline $\begin{array}{l}\text { Continuous } \\
\text { Darkness }\end{array}$ & 367.300 & 384.233 & 391.700 & $381.078 \pm 12.502$ & $4.42 \%$ \\
\hline $\begin{array}{l}\text { Continuous Light } \\
\text { (Control) }\end{array}$ & 401.900 & 441.134 & 416.500 & $419.844 \pm 19.829$ & $10.37 \%$ \\
\hline
\end{tabular}




\section{Study CP: Coprophagy Prevention Method}

The triplicate that experienced a filter paper change every 12 hours produced $83.8 \%$ of total egesta in the first 12 hours (Table 4). In the triplicates that experienced a filter paper change every 12 and 24 hours, $89.6 \%$ of total egesta was produced on average in the first 24 hours (Table 4).

Table 4. Egesta production for each petri dish over 48 hours: Study CP.

\begin{tabular}{lcccccc}
\hline Treatment & $\begin{array}{c}\text { Time } \\
(\mathbf{h r})\end{array}$ & $\begin{array}{c}\text { Sample 1 } \\
(\mathbf{m g})\end{array}$ & $\begin{array}{c}\text { Sample 2 } \\
(\mathbf{m g})\end{array}$ & $\begin{array}{c}\text { Sample 3 } \\
(\mathbf{m g})\end{array}$ & $\begin{array}{c}\text { Triplicate } \\
\text { Avg (mg) }\end{array}$ & $\begin{array}{c}\text { Triplicate } \\
\text { SD }\end{array}$ \\
\hline Filter Change & 12 & 16.300 & 18.400 & 18.900 & 17.867 & 1.380 \\
Every 12 Hours & 24 & 2.600 & 1.700 & 1.900 & 2.067 & 0.473 \\
& 36 & 0.700 & 1.000 & 0.500 & 0.733 & 0.252 \\
& 48 & 0.700 & 0.270 & 1.000 & 0.657 & 0.367 \\
\hline Filter Change & 24 & 19.100 & 17.600 & 11.000 & 15.900 & 4.309 \\
Every 24 Hours & 48 & 4.900 & 1.600 & 1.400 & 2.633 & 1.966 \\
\hline $\begin{array}{l}\text { Filter Change } \\
\text { Every 48 Hours }\end{array}$ & 48 & 17.000 & 14.600 & 13.500 & 15.033 & 1.790 \\
(Control) & & & & & \\
\hline
\end{tabular}

Figure 5a shows the total egesta produced on average by each triplicate in Study CP. The $W_{e / f}$ term (Fig. 5b) is a better representation of the data since the range of fresh weight was much wider for the triplicate that experienced a paper disc change every 24 hours. The standard deviation of fresh weight for the 24-hour triplicate was 89.960 compared to 26.028 and 36.913 for the 48- and 12-hour triplicates, respectively (Table 3).

Figure 6a shows the average $W_{\text {elf }}$ produced by each triplicate. Since data collection occurred every 12 hours for one triplicate, a rough kinetics model could be determined (Fig. 6b). Multiple curve fit models were tested on this data set and the two best fits (as determined by $\mathrm{R}^{2}$ ) were the 3-term exponential model and the cubic model. The equation for the 3-term exponential curve is given in equation 6 and the cubic polynomial curve is given in equation 7. Since the exponential model had the best fit, this model was forced fit to the other data sets. The third term in the exponential function is considered the growth or egestion rate and can be used to compare the relative speed at which the function reaches a change in rate of zero.

$$
\begin{gathered}
y=1.780-1.780 e^{-0.1576 x} \\
y=0.0161+0.1850 x-0.0062 x^{2}+6.467 E^{-5} x^{3}
\end{gathered}
$$




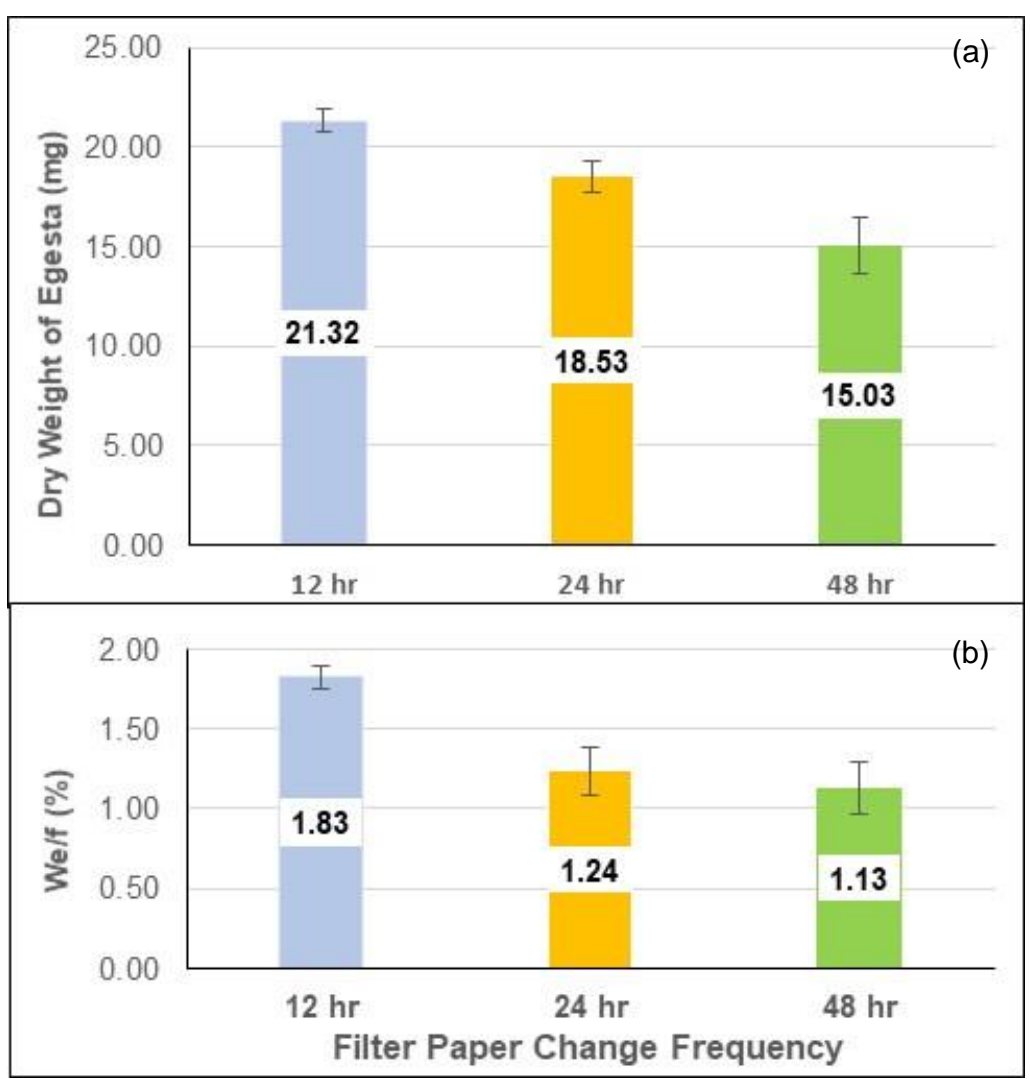

Figure 5. Average total egesta produced (mg) by each triplicate over the course of 48 hours (a). Average $W_{e / f}$ produced over the course of 48 hours (b).
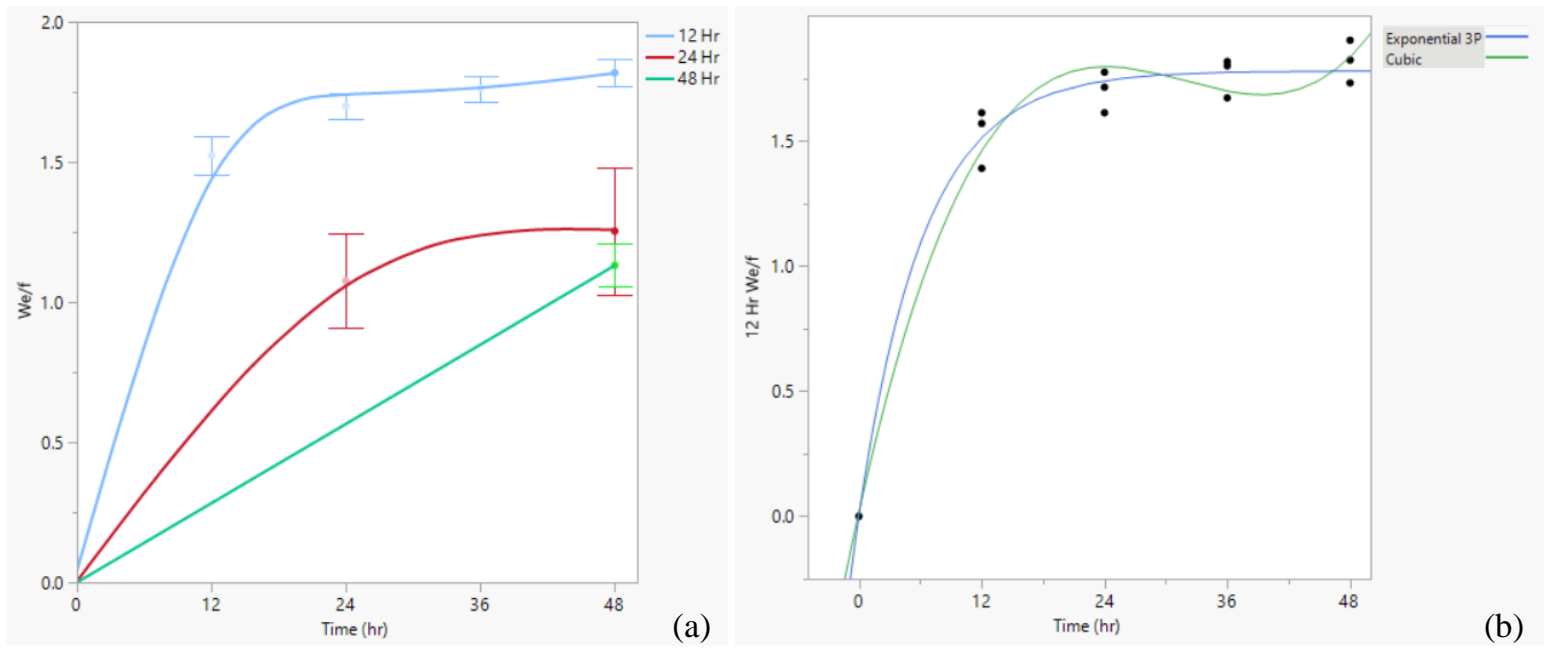

Figure 6. Average $W_{e / f}$ produced over the course of 48 hours (a). Egestion kinetics for the filter paper change frequency: Every 12 hours (b). 
The exponential kinetics model found for the triplicate that experienced a filter paper disc change every 12 hours was then applied to the other two paper disc change frequencies (Table 5). Inverse predictions were used to find the time at which $90 \%, 75 \%$, and $50 \%$ of the total $W_{e / f}$ had been produced. Despite the different growth rates, it could be concluded that $90 \%$ of the total $W_{e / f}$ was produced after just over 24 hours for all the filter paper disc change frequencies that could be considered (Table 6).

Table 5. Curve fits for each data set: Study CP.

\begin{tabular}{lcccc}
\hline Variable Group & $\begin{array}{c}\mathbf{R}^{2} \text { Value } \\
\text { Cubic }\end{array}$ & $\begin{array}{c}\mathbf{R}^{2} \text { Value } \\
\text { Exponential }\end{array}$ & $\begin{array}{c}\text { RMSE } \\
\text { Exponential }\end{array}$ & $\begin{array}{c}\text { Growth Rate Magnitude } \\
\text { of Exponential Model }\end{array}$ \\
\hline Filter Change Every 12 Hours & 0.983 & 0.989 & 0.081 & 0.158 \\
Filter Change Every 24 Hours & $\mathrm{X}$ & 0.852 & 0.283 & 0.075 \\
Filter Change Every 48 Hours (Control)* & $\mathrm{X}$ & $\mathrm{X}$ & $\mathrm{X}$ & 0.048 \\
\hline
\end{tabular}

* R and RMSE values for the 48-hour triplicate were very large due to a lack of data.

Table 6. Time (hr) that percentages of total $W_{e / f}$ were produced according to the kinetic models.

\begin{tabular}{lccc}
\hline Treatment & $\mathbf{5 0 \%} \boldsymbol{W}_{\boldsymbol{e} / \boldsymbol{f}}$ & $\mathbf{7 5 \%} \boldsymbol{W}_{\boldsymbol{e} / \boldsymbol{f}}$ & $\mathbf{9 0 \%} \boldsymbol{W}_{\boldsymbol{e} / \boldsymbol{f}}$ \\
\hline Filter Change Every 12 Hours & 4.53 & 9.22 & 16.0 \\
Filter Change Every 24 Hours & 8.89 & 17.44 & 27.79 \\
Filter Change Every 48 Hours (Control)* & $\mathrm{X}$ & $\mathrm{X}$ & $\mathrm{X}$ \\
\hline
\end{tabular}

* Inverse predictions could not be estimated using the model generated for the 48-hour triplicate due to a lack of data and consequently insignificant p-value for the estimate.

\section{Study LC: Light Conditions}

Figure 7a shows the total egesta produced on average by each triplicate in Study LC. Darkness conditions resulted in almost double the $W_{e / f}$ value compared to the control $(97.8 \%$ more) (Table 7; Fig. 7b). The $W_{e / f}$ value for the control in this study was lower than the control treated under the same conditions in Study CP: 0.82 vs 1.13, respectively. Figure 8a depicts the triplicate after 48 hours depurated in continuous light and Figure $8 \mathrm{~b}$ shows the triplicate after 48 hours depurated in continuous darkness. The egesta is mainly deposited near or next to the earthworms in Figure 8a while the egesta is scattered about the petri dishes in Figure 8b. 
Table 7. Egesta production after 48 hours: Study LC.

\begin{tabular}{lccccc}
\hline Treatment & $\begin{array}{c}\text { Sample } \\
\text { Number }\end{array}$ & $\begin{array}{c}\text { Total Egesta } \\
\text { Produced }(\mathbf{m g})\end{array}$ & $\boldsymbol{W}_{\boldsymbol{e} / \boldsymbol{f}}$ & $\begin{array}{c}\text { Triplicate } \\
\text { Average } \boldsymbol{W}_{\boldsymbol{e} / \boldsymbol{f}}\end{array}$ & SD \\
\hline Continuous Light & 1 & 9.4000 & 0.7796 & & \\
(Control) & 2 & 10.3000 & 0.7783 & 0.8234 & 0.0770 \\
& 3 & 11.4000 & 0.9124 & & \\
\hline Continuous & 1 & 16.6000 & 1.5065 & & 0.2426 \\
Darkness & 2 & 22.0000 & 1.9086 & 1.6291 & \\
& 3 & 17.3000 & 1.4722 & & \\
\hline
\end{tabular}

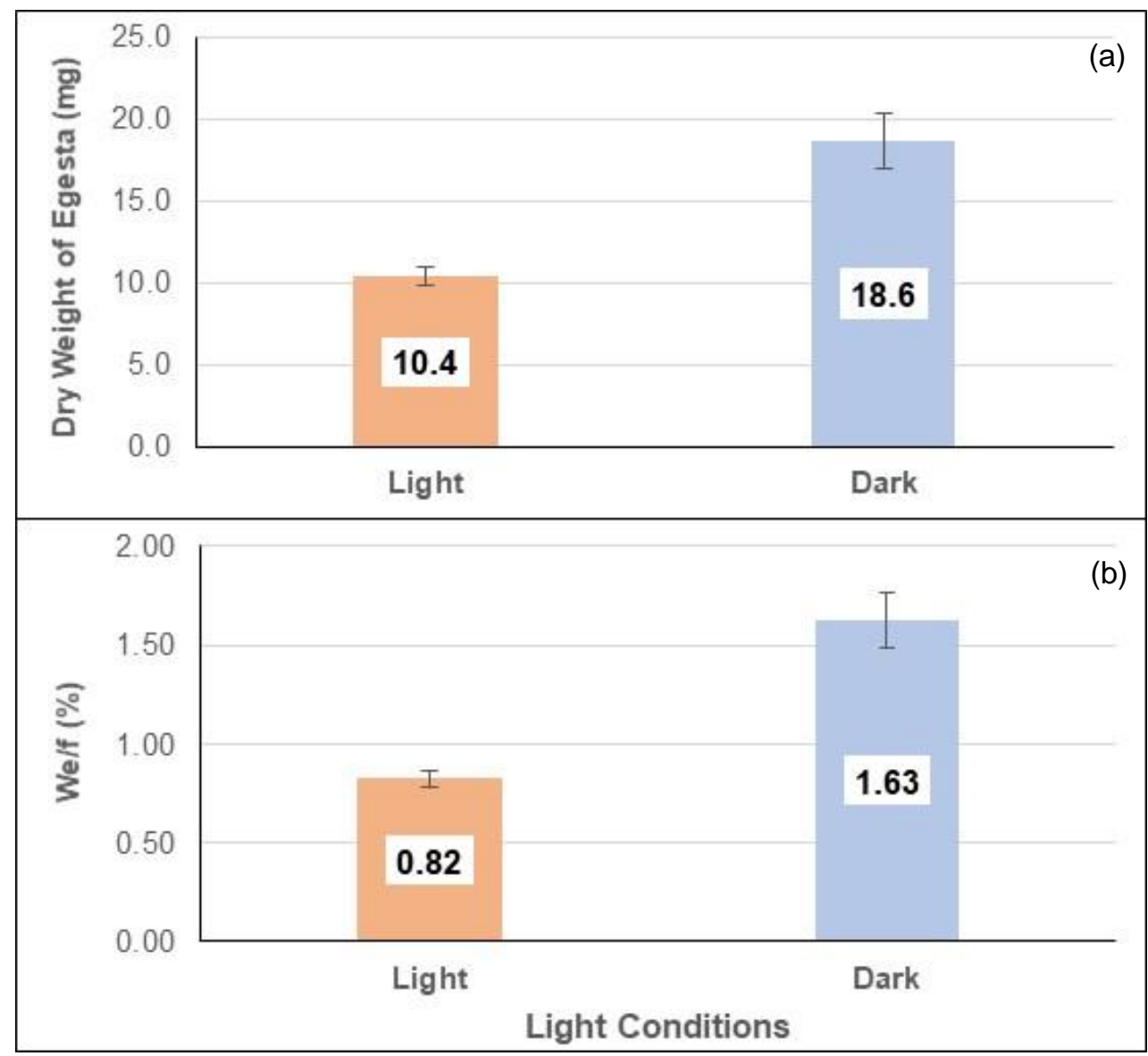

Figure 7. Average total egesta produced (mg) by each triplicate over the course of 48 hours (a). Average $W_{e / f}$ produced over the course of 48 hours (b). 


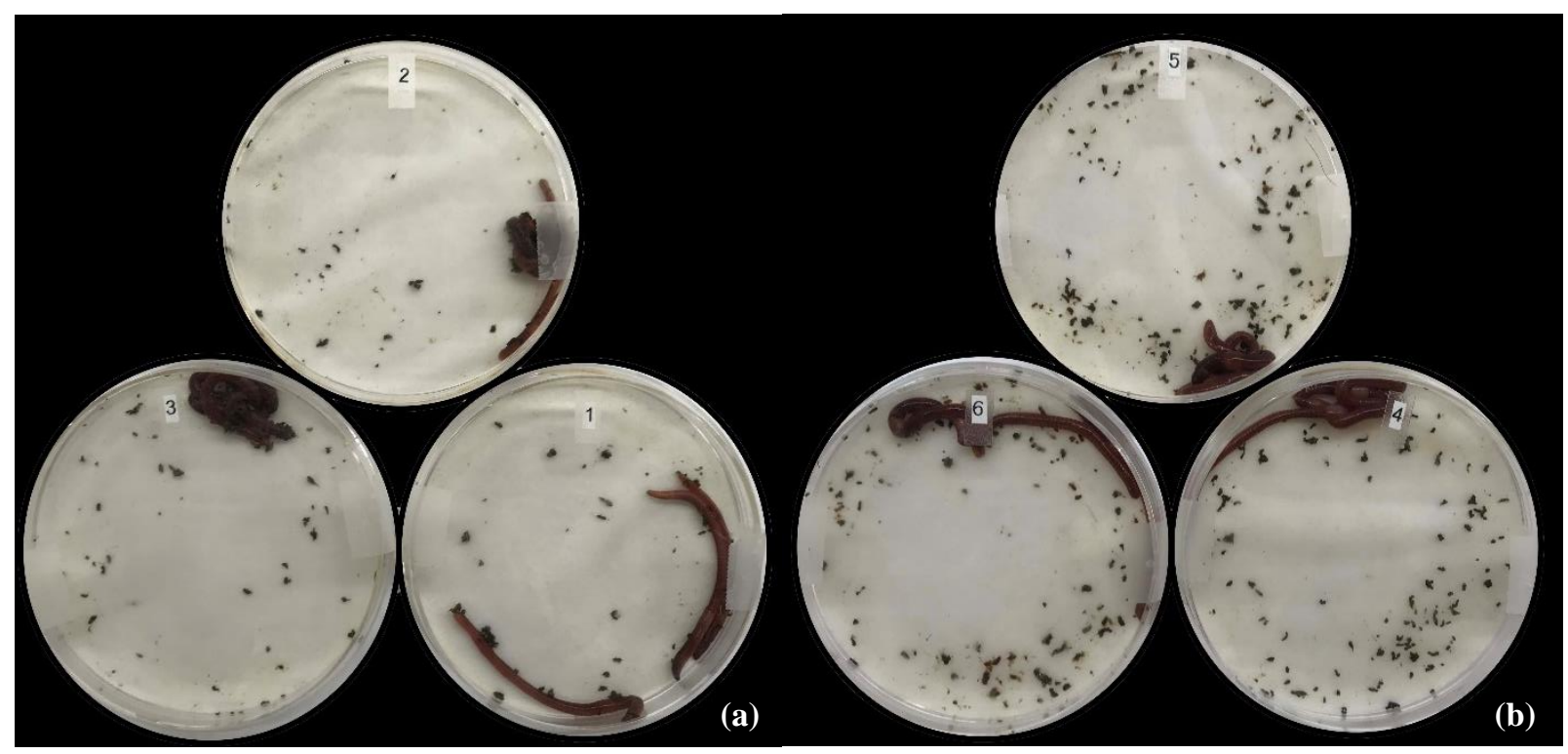

Figure 8. Triplicate after 48 hours of continuous light (a). Triplicate after 48 hours of continuous darkness (b).

\section{Discussion}

The percentage of egesta per mg of initial fresh weight $\left(W_{e / f}\right)$ produced in each triplicate suggests that earthworms experiencing either a filter paper disc change every 12 hours under continuous light or consistent darkness during depuration will void their guts most efficiently. The $W_{e / f}$ values for the 12-hour triplicate in Study CP and the earthworms depurated in total darkness in Study LC were comparable: 1.83 and 1.63, respectively. Though the $W_{e / f}$ value was the highest for the treatment triplicate that experienced a filter paper disc change every 12 hours, attending to the earthworms every 12 hours was labor intensive and the egesta removal after the initial 12 hours was minimal (Table 4). If labor is a limitation, it would benefit researchers to adjust the light conditions of the depuration rather than the frequency of egesta removal, or to perform egesta removal only after the initial 12 hours since the egesta production, and therefore the chance of reingestion, is much smaller after that period.

An unexpected result in Study CP was the lack of observations of reingested material in the anterior portion of the gastrointestinal tract of the earthworms due to coprophagy. This lack of visible reingested material suggests that the $W_{e / f}$ values could have been influenced by another factor, namely moisture content of the petri dish. Due to the nature of the egesta collection for the 12-hour triplicate, the moisture content of the petri dishes was better maintained and more consistent. Culturing methods have established that stable moisture content is ideal (Lowe \& 
Butt, 2005) and previous observations saw the highest mortality among earthworms who experienced moisture level fluctuation (Messer and Wilkie, unpublished). Future iterations of Study CP could standardize moisture content in the petri dishes across triplicates and ideally analyze light conditions and coprophagy simultaneously.

A novel aspect of Study CP is the egestion kinetics model that took into consideration $W_{e / f}$ values on a time scale smaller than 24 hours. This model can be used to provide justification for shorter depuration times based on the desired sensitivity of the bioaccumulation test being conducted and provide more insight into E. fetida gut transit times. Since $75 \%$ of egesta production occurred within the first 17.5 hours (Table 6), egesta removal after the first 12 hours was more impactful than subsequent egesta removal after 24 hours.

In Study LC, the earthworms under continuous darkness not only produced more egesta than the earthworms under continuous light, but the spread of egesta implies a larger area of locomotion (Figure 8). These assumptions are supported by the findings of Mishra et al. (2019), who found that maximum activity occurred in the dark compared to low intensity exposure to white, blue, green and red LED lights. Blue light was found to have the smallest effect on earthworms' biochemical and biological parameters (Mishra et al., 2019). Though egesta patterns indicate a wider area of movement, continuous observation would be necessary to differentiate between the same level of activity in a localized area. The method outlined by Xu et al. (2020) for quantifying the locomotor activity of earthworms could be applied here under bright light and low intensity blue light to simulate activity levels in the dark.

For future work, it would be useful to include other worm species and analyze the effect that filter paper changes have on BAF values. Bioaccumulation tests would benefit from the inclusion of other worm species since surface dwelling (epigeic) and burrowing earthworms (endogeic) interact with the terrestrial ecosystem differently. Burrowing earthworms might encounter an entirely different contaminated environment and respond to it differently. As for the effect on BAF values, it would be expected that more complete gut voidance would increase the accuracy of BAF values, but the increased handling involved in coprophagy prevention might influence the metabolism of the subject and lead to detoxification of the contaminant (Porfido et al., 2019). 


\section{Conclusion}

Darkness conditions and 12-hour filter paper disc replacements under continuous light during gut voidance increased egesta generation and $W_{e / f}$ values in E. fetida. The significantly

increased production of egesta in Study CP for the triplicates that had egesta removed every 12 hours suggests that a coprophagy prevention method would be beneficial. The kinetics model supports the use of depuration periods shorter than 48 hours. However, removing egesta every 12 hours could prove to be labor intensive for studies with a larger population of petri dishes. The increased production of egesta in Study LC suggests that earthworms depurate more completely in continuous darkness than under fluorescent light. This has implications for bioaccumulation test protocols which call for constant light exposure. The next step in this research would be to assess coprophagy prevention under darkness conditions to directly compare the treatments.

\section{Acknowledgements}

This research was conducted as part of the 2020-2021 CALS University Scholars Program and SWS 4911: Supervised Research in Soil and Water Sciences, at the Bioenergy and Sustainable Technology Laboratory, Soil and Water Sciences Department, UF/IFAS.

\section{References}

Abd Aziz, A., Lee, B.-T., Han, H.-J., \& Kim, K.-W. (2019). Assessment of the stabilization of heavy metal contaminants in soils using chemical leaching and an earthworm bioassay. Environmental Geochemistry and Health, 41(1), 447-460. https://doi.org/10.1007/s10653-018-0173-1

Arnold, R. E., \& Hodson, M. E. (2007). Effect of time and mode of depuration on tissue copper concentrations of the earthworms Eisenia andrei, Lumbricus rubellus and Lumbricus terrestris. Environmental Pollution, 148(1), 21-30. https://doi.org/10.1016/j.envpol.2006.11.003

ASTM. (2021). E1676-12(2021) Standard guide for conducting laboratory soil toxicity or bioaccumulation tests with the Lumbricid earthworm Eisenia fetida and the Enchytraeid potworm Enchytraeus albidus. ASTM International, West Conshohocken, PA. https://doi.org/10.1520/E1676-12R21

Callaham, M. A., \& Hendrix, P. F. (1998). Impact of earthworms (Diplocardia: Megascolecidae) on cycling and uptake of nitrogen in coastal plain forest soils from northwest Florida, USA. Applied Soil Ecology, 9(1-3), 233-239. https://doi.org/10.1016/S0929$\underline{1393(97) 00048-6}$ 
Carter, L. J., Ryan, J. J., \& Boxall, A. B. A. (2016). Effects of soil properties on the uptake of pharmaceuticals into earthworms. Environmental Pollution, 213, 922-931. https://doi.org/10.1016/j.envpol.2016.03.044

Costanza, J., Lynch, D. G., Boethling, R. S., \& Arnot, J. A. (2012). Use of the bioaccumulation factor to screen chemicals for bioaccumulation potential. Environmental Toxicology and Chemistry, 31(10), 2261-2268. https://doi.org/10.1002/etc.1944

Crossley, D. A., Blood, E. R., Hendrix, P. F., \& Seastedt, T. R. (1995). Turnover of cobalt-60 by earthworms (Eisenia foetida) (Lumbricidae, Oligochaeta). Applied Soil Ecology, 2(2), 71 75. https://doi.org/10.1016/0929-1393(94)00045-9

Dindal, D. L. (1990). Soil Biology Guide. John Wiley \& Sons, New York, NY.

Diercxsens, P., de Weck, D., Borsinger, N., Rosset, B., \& Tarradellas, J. (1985). Earthworm contamination by PCBs and heavy metals. Chemosphere, 14(5), 511-522. https://doi.org/10.1016/0045-6535(85)90244-9

Doube, B. M., Schmidt, O., Killham, K., \& Correll, R. (1997). Influence of mineral soil on the palatability of organic matter for lumbricid earthworms: A simple food preference study. Soil Biology and Biochemistry, 29(3-4), 569-575. https://doi.org/10.1016/S0038$\underline{0717(96) 00032-6}$

González, G., \& Zou, X. (1999). Earthworm influence on N availability and the growth of Cecropia schreberiana in tropical pasture and forest soils. Pedobiologia, 43, 824-829. https://data.fs.usda.gov/research/pubs/iitf/ja_iitf_1999_Gonzalez002.pdf

Harper, E. H. (1905). Reactions to light and mechanical stimuli in the earthworm Perichaeta bermudensis (Beddard). The Biological Bulletin, 10(1), 17-34. https://www.journals.uchicago.edu/doi/pdf/10.2307/1535582

Hu, S., Zhang, W., Li, J., Lin, K., \& Ji, R. (2016). Antioxidant and gene expression responses of Eisenia fetida following repeated exposure to BDE209 and $\mathrm{Pb}$ in a soil-earthworm system. Science of the Total Environment, 556, 163-168. https://doi.org/10.1016/j.scitotenv.2016.02.194

Lachnicht, S., Hendrix, P., \& Zou, X. (2002). Interactive effects of native and exotic earthworms on resource use and nutrient mineralization in a tropical wet forest soil of Puerto Rico. Biology and Fertility of Soils, 36(1), 43-52. https://doi.org/10.1007/s00374-002$\underline{0501-5}$

Lemtiri, A., Liénard, A., Alabi, T., Brostaux, Y., Cluzeau, D., Francis, F., \& Colinet, G. (2016). Earthworms Eisenia fetida affect the uptake of heavy metals by plants Vicia faba and Zea mays in metal-contaminated soils. Applied Soil Ecology, 104, 67-78. https://doi.org/10.1016/j.apsoil.2015.11.021

Lowe, C. N., \& Butt, K. R. (2005). Culture techniques for soil dwelling earthworms: A review. Pedobiologia , 49(5), 401-413. https://doi.org/10.1016/j.pedobi.2005.04.005

Mishra, C. S. K., Nayak, S., \& Samal, S. (2019). Low intensity light effects on survivability, biomass, tissue protein and enzyme activities of the earthworm Eudrilus eugeniae (Kinberg). Invertebrate Survival Journal, 16(1), 8-14. https://doi.org/10.25431/1824$\underline{307 X / i s j . v 0 i 0.8-14}$ 
Morgan, J. E, \& Morgan, A. J. (1989). Zinc sequestration by earthworm (Annelida: Oligochaeta) chloragocytes. Histochemistry, 90(5), 405-411. https://doi.org/10.1007/BF00508320

Mount, D. R., Dawson, T. D., \& Burkhard, L. P. (1999). Implications of gut purging for tissue residues determined in bioaccumulation testing of sediment with Lumbriculus variegatus. Environmental Toxicology and Chemistry, 18(6), 1244-1249. https://doi.org/10.1002/etc.5620180625

Nahmani, J., Hodson, M. E., \& Black, S. (2007a). A review of studies performed to assess metal uptake by earthworms. Environmental Pollution, 145(2), 402-424. https://doi.org/10.1016/j.envpol.2006.04.009

Nahmani, J., Hodson, M. E., \& Black, S. (2007b). Effects of metals on life cycle parameters of the earthworm Eisenia fetida exposed to field-contaminated, metal-polluted soils. Environmental Pollution, 149(1), 44-58. https://doi.org/10.1016/j.envpol.2006.12.018

OECD. (2010). Test No. 317: Bioaccumulation in terrestrial Oligochaetes, OECD Guidelines for the Testing of Chemicals, Section 3, OECD Publishing, Paris. https://doi.org/10.1787/9789264090934-en.

Oorts, K., Smolders, E., Lanno, R., \& Chowdhury, M. J. (2021). Bioavailability and ecotoxicity of lead in soil: Implications for setting ecological soil quality standards. Environmental Toxicology and Chemistry, 40(7), 1950-1963. https://doi.org/10.1002/etc.5051

Panzarino, O., Hyršl, P., Dobeš, P., Vojtek, L., Vernile, P., Bari, G., Terzano, R., Spagnuolo, M., $\&$ de Lillo, E. (2016). Rank-based biomarker index to assess cadmium ecotoxicity on the earthworm Eisenia andrei. Chemosphere, 145, 480-486. https://doi.org/10.1016/j.chemosphere.2015.11.077

Porfido, C., Allegretta, I., Panzarino, O., Laforce, B., Vekemans, B., Vincze, L., de Lillo, E., Terzano, R., \& Spagnuolo, M. (2019). Correlations between As in earthworms' coelomic fluid and As bioavailability in highly polluted soils as revealed by combined laboratory x-ray techniques. Environmental Science \& Technology, 53(18), 10961-10968. https://doi.org/10.1021/acs.est.9b02310

Richards, K. S., \& Ireland, M. P. (1978). Glycogen-lead relationship in the earthworm Dendrobaena rubida from a heavy metal site. Histochemistry, 56(1), 55-64. https://doi.org/10.1007/BF00492253

Richardson, J. B., Renock, D. J., Görres, J. H., Jackson, B. P., Webb, S. M., \& Friedland, A. J. (2016). Nutrient and pollutant metals within earthworm residues are immobilized in soil during decomposition. Soil Biology and Biochemistry, 101, 217-225. https://doi.org/10.1016/i.soilbio.2016.07.020

Sheppard, S. C., Evenden, W. G., \& Cornwell. T. C. (1997). Depuration and uptake kinetics of I, $\mathrm{Cs}, \mathrm{Mn}, \mathrm{Zn}$ and $\mathrm{Cd}$ by the earthworm (Lumbricus terrestris) in radiotracer-spiked litter. Environmental Toxicology and Chemistry, 16(10), 2106-2112. https://doi.org/10.1002/etc.5620161017

Shi, Z., Tang, Z., \& Wang, C. (2017). A brief review and evaluation of earthworm biomarkers in soil pollution assessment. Environmental Science and Pollution Research, 24(15), 1328413294. https://doi.org/10.1007/s11356-017-8784-0 
Tang, R., Ding, C., Ma, Y., Wan, M., Zhang, T., \& Wang, X. (2018). Main controlling factors and forecasting models of lead accumulation in earthworms based on low-level leadcontaminated soils. Environmental Science and Pollution Research, 25(23), 2311723124. https://doi.org/10.1007/s11356-018-2436-X

Tatsi, K. (2017). The biological effects of engineered nanomaterials on soil organisms: surface coating and age matter. PhD Research Thesis, University of Plymouth, UK. http://hdl.handle.net/10026.1/11034

Tatsi, K., Shaw, B. J., Hutchinson, T. H., \& Handy, R. D. (2018). Copper accumulation and toxicity in earthworms exposed to $\mathrm{CuO}$ nanomaterials: Effects of particle coating and soil ageing. Ecotoxicology and Environmental Safety, 166, 462-473.

https://doi.org/10.1016/j.ecoenv.2018.09.054

Toutain, P. L., \& Bousquet-Mélou, A. (2004). Bioavailability and its assessment. Journal of Veterinary Pharmacology and Therapeutics, 27(6), 455-466. https://doi.org/10.1111/j.1365-2885.2004.00604.X

USEPA. (2000). Methodology for deriving ambient water quality criteria for the protection of human health. EPA-822-B-00-004. US EPA, Office of Science and Technology, Office of Water, Washington, DC. https://www.epa.gov/wqc/methodology-deriving-ambientwater-quality-criteria-protection-human-health-2000-documents

Vijver, M. G., Vink, J. P. M., Jager, T., Wolterbeek, H. T., van Straalen, N. M., \& van Gestel, C. A. M. (2005). Biphasic elimination and uptake kinetics of $\mathrm{Zn}$ and $\mathrm{Cd}$ in the earthworm Lumbricus rubellus exposed to contaminated floodplain soil. Soil Biology and Biochemistry, 37(10), 1843-1851. https://doi.org/10.1016/j.soilbio.2005.02.016

Ward, A., Liu, J., Feng, Z., \& Xu, X. Z. S. (2008). Light-sensitive neurons and channels mediate phototaxis in C. elegans. Nature Neuroscience, 11(8), 916-922. https://doi.org/10.1038/nn.2155

Wijayawardena, M. A. A., Megharaj, M., \& Naidu, R. (2017). Bioaccumulation and toxicity of lead, influenced by edaphic factors: using earthworms to study the effect of $\mathrm{Pb}$ on ecological health. Journal of Soils and Sediments, 17, 1064-1072. https://doi.org/10.1007/s11368-016-1605-0

Wijayawardena, M. A. A., Megharaj, M., Naidu, R., \& Stojanovski, E. (2018) Chronic and reproductive toxicity of cadmium, zinc, and lead in binary and tertiary mixtures to the earthworm (Eisenia fetida). Journal of Soils and Sediments, 18, 1602-1609. https://doi.org/10.1007/s11368-017-1877-z

Xiao, R., Liu, X., Ali, A., Chen, A., Zhang, M., Li, R., Chang, H., \& Zhang, Z. (2021). Bioremediation of Cd-spiked soil using earthworms (Eisenia fetida): Enhancement with biochar and Bacillus megatherium application. Chemosphere, 264(2), 128517. https://doi.org/10.1016/j.chemosphere.2020.128517

Xu, T., Zhao, W., Miao, J., Zhang, B., Yang, X., Sheng, G. D., \& Yin, D. (2020). A sensitive optical-based test method for the locomotor activity of earthworms. Science of the Total Environment, 715, 136966. https://doi.org/10.1016/j.scitotenv.2020.136966 